\title{
Kosmetika Halal atau Haram serta Sertifikasinya
}

\section{Muchtaridi}

Departemen Analisis Farmasi dan Kimia Medisinal, Fakultas Farmasi Universitas Padjadjaran, 45363, Indonesia email: muchtaridi@unpad.ac.id

\section{ABSTRAK}

Kosmetika sebagai produk dalam memelihara kecantikan semakin berkembang seiring dengan perkembangan bioteknologi. Saat ini, seiring dengan poerkembangan teknologi, produk kosmetika di Indonesia semakin banyak dan beragam, hingga kita sulit menelisik bahan-bahan yang haram di dalamnya. Oleh karena itu, agar kita waspada, ada baiknya jika kita mengetahui titik-kritis haram dalam kosmetika. Artikel mini review ini akan membahas apakah kosmetika yang ada saat ini halal atau haram? Perlukah sertifikasi halal diterapkan?

Kata kunci: kosmetika, halal, haram

\section{PENDAHULUAN}

Bukan hanya obat yang harus diperhatikan sisi halal tidaknya suatu produk farmasi. Jika kita lihat website www.halalmui.org, hanya ada beberapa item produk kosmetika yang telah terdaftar sebagai produk halal, lalu yang ratusan bahkan ribuan produk lainnya bagaimana? apakah haram?

Bahkan, obat yang disertifikat halal hampir dikatakan tidak ada. Fenomena ini yang harus menjadi perhatian para muslimah Indonesia, karena bagaimanapun mayoritas wanita Indonesia adalah muslim. Kalau kita simak bagaimana pembuatan kosmetika, ternyata titik-titik kritis halal sangat banyak dibandingkan obat atau makanan.

Memang, kecantikan adalah anugerah Tuhan yang harus kita pelihara, namun bagi muslimah, merawat dan memelihara kecantikan bukan artinya harus menghalalkan segala cara.

Kosmetika sebagai produk dalam memelihara kecantikan semakin berkembang seiring dengan perkembangan bioteknologi. Menurut Peraturan Menteri Kesehatan RI Tahun 1976, kosmetika adalah bahan atau campuran bahan untuk digosokkan, dilekatkan, dituangkan, dipercikkan atau disemprotkan pada, dimasukkan dalam, dipergunakan pada badan manusia dengan maksud membersihkan, memelihara, menambah daya tarik dan mengubah rupa dan tidak termasuk golongan obat. Zat tersebut tidak boleh mengganggu kulit dan kesehatan tubuh secara keseluruhan.

Dari pengertian tersebut, kosmetika digunakan baik pada bagian luar maupun dalam tubuh manusia. Sesuai ajaran Islam, dua hal yang harus diperhatikan dalam penggunaan produk kosmetika adalah kebersihan dan kesucian. Artinya, kosmetika harus halal dan suci. 


\section{Titik Kritis Kosmetika Haram}

Saat ini, seining dengan perkembangan teknologi, produk kosmetika di Indonesia semakin banyak dan beragam, hingga kita sulit menelisik bahan-bahan yang haram di dalamnya. Oleh karena itu, agar kita waspada, ada baiknya jika kita mengetahui titik-kritis haram dalam kosmetika.

Titik-titik kritis haram tersebut yang harus diwaspadai terutama sumber bahan dasar pembuatan kosmetika, bisa jadi berasal dari hewan atau bagian organ manusia. Jika bahan dasamya berasal dari babi atau bagian organ manusia, maka jelas produk tersebut dinyatakan haram, karena berdasarkan QS; Al-Baqarah:173, penggunaan apapun berasal dari babi adalah haram, dan fatwa MUI No.2/MunasVI/MUI/2000, penggunaan kosmetika yang mengandung atau berasal dari bagian organisme manusia, hukumnya adalah haram. Kalaupun berasal dari hewan yang bukan babi, jika hewan tersebut tidak disembelih secara islam, maka dinyatakan haram.

Sedangkan, zat pembuat kosmetika yang mejadi titik kritis haram adalah pertama, zat aktif dari produk kosmetik tersebut, misalnya, kolagen dan elastin. Kolagen dan elastin berfungsi untuk menambah elatisitas kulit, biasanya terdapat dalam krim atau lotion. Kolagen berasal dari tulang hewan, jika kolagennya berasal dari hewan yang disembelih secara islam, tentu tidak masalah kehalalannya. Namun, yang menjadi masalah justru sumbernya yang tidak jelas, sehingga membuat produk ini menjadfi syubhat.

Kedua, zat-zat penstabil sebagai bahan dasar. Lipstik, deodorant, eye shadow berbahan dasar (basis) garam-garam asam lemak, seperti lauril palmitat, gliseril monostearat. Garam asam lemak ini kemungkinan besar didapat dari hewan. Bahan penstabil tersebut harus halal sumbernya dan cara penyembelihan atau pengolahan.

Ketiga, asam lemak esensial. Beberapa jenis asam lemak yang sering digunakan adalah asam linolenat, asam linoleat dan asam arakidonat sebagai antioksidan. Asam-asam lemak tersebut banyak digunakan dalam kosmetika khususnya untuk perawatan kulit. Yang perlu diwaspadai adalah sumber asam lemak apakah dari hewan yang halal dan disembelih dengan cara islami juga bahan penstabil yang digunakan karena asam-asam lemak tersebut adalah golongan yang yang mudah teroksidasi atau tidak stabil sehingga membutuhkan bahan penstabil ketika digunakan.

Ketiga, hormon dan ekstrak kelenjar. Hormon dan ekstrak kelenjar alami yang sedang naik popularitasnya saat ini adalah ekstrak plasenta. Dalam kamus Ingredient Cosmetic, dinyatakan bahwa ekstrak plasenta adalah ekstrak yang berasal dari plasenta bayi yang baru lahir atau kita kenal sebagai tali puser atau ari-ari yang secara tradisional sering dikubur agar tidak digunakan untuk kepentingan yang melanggar agama. Namun, masih dalam kamus yang sama plasenta protein, plasenta enzim dan plasenta lipid adalah zat yang diambil dari plasenta hewan, seperti plasenta kambing, sapi dan babi. ${ }^{1}$

Ekstrak plasenta memiliki khasiat menstabilkan sitem hormonal sehingga zat ini dapat meningkatkan produksi susu, melancarkan haid, melancarkan peredaran darah, menstabilkan penderita menopause, meningkatkan kesuburan bagi pria dan wanita, bahkan dapat meningkatkan gairah seksual. 
Selain itu, zat ini mengandung Senescent Cell Activating Factors (SCAF) sebagai biogenik stimulator yang dapat meningkatkan atau mempercepat dan reproduksi sel kulit dan meregenerasi sel yang rusak. Sedangkan karena kandungan asam aminonya yang tinggi, ekstrak ini dapat manyembuhkan penyakit yang berhubungan dengan sistem syaraf. Bahkan, Watanabe dkk (2002) menyatakan bahwa L-Triptopan yang diisolasi dari plasenta manusia memberikan aktivitas antioksidan yang baik dengan menghambat sel sitokrom P-450 yang terikat pada lipid peroksidasi. ${ }^{2}$

Enzim SOD dalam ekstrak tersebut berfungsi sebagai antioksidan. Jadi, ekstrak plasenta ini harus diwaspadai sumbernya dan jika dari hewan perlu diwaspadai cara penyembelihannya dan jika dari produk mikrobial perlu diperhatikan titik kritisnya.

Dari keterangan titik kritis haram tadi, dapat ditarik kesimpulahan bahwa terlepas masih peliknya tentang sertifikasi kehalalan makanan, tetapi sertifikasi halal kosmetika dan obat perlu segera diterapkan. Jika para pakar Teknologi Resep atau ahli farmasi berdalih bahwa selama zat haram itu adalah obat yang baik, maka penggunaaanya masih bisa ditoleransi, hal itu bisa dibetulkan dalam kondisi darurot sesuai apa yang disampaikan Dr. Yusuf Qordhowi dalam bukunya Halam Haram fil Islam, tetapi yang harus digaris bawahi, "selama ada zat yang memiliki khasiat yang sama dengan zat haram itu, maka tetap zat tersebut dinyatakan haram" mungkin inilah prinsip yang harus diterapkan jika sertifikasi obat dan kosmetik suatu saat ditrerapkan.

\section{Kosmetik dari Herbal Belum Tentu Halal?}

Fenomena kosmetika herbal semakin marak seiring slogan pemerintah "kembali ke alam". Bahkan, fenomena tabir surya dari bahan alam pun semakin marak, padahal penelitian kami selama 5 tahun terakhir tabir surya dari herbal sangatlah tiudak stabil jika tidak ditambah penstabil dari senyawa kimia sintesis. Namun, kosmetik dari herbal belum tentu halal selam produk itu tidak dipastikan kehalalannya oleh lembaga resmi seperti LPOM MUI.

Bukan masalah herbalnya yang tidak halal, tapi bagaimanapun sediaan kosmetik diracik dengan pengisi bahan kimia yang tidak sedikit dipertanyakan kehalalannya. Berikut beberapa pengisi yang harus dicurigai kehalalannya: ${ }^{3}$

- Ekstrak plasenta

- Kolagen dan elastin

- Lesitin

- Lemak turunan gliserida

- Hormon-hormon estrogen

- Asama lemak tak jenuh

- Gelatin

- Cairan amnion atau cairan ketuban

- Gliserin

\section{Tuntutan Muslim}

Lalu, setelah kita tahu bahwa titik kritis haram kosmetika sangat rawan apa yang dilakukan? Menuntut agar produk kosmetika berlabel halal?. Saat ini, dipastikan tuntukan kita sebagai muslim sulit tercapai, hal ini disebabkan hal-hal berikut. 
Kesadaran yang kecil dari muslimah Indonesia terhadap kehalalan suatu produk. Masalah kesadaran umat muslim Indonesia memang masih jauh kalau misalnya dibandingkan Negara tetangga kita Malaysia. Muslim Negara jiran masih punya ketakutan ketika mereka berhadapan produk yang tidak berlabel halal, namun muslim di Negara kita masih banyak yang menganut prinsip selama zat haram itu adalah obat yang baik, maka penggunaaanya masih bisa ditoleransi, bahkan infortainment di televisi yang menampilkan kecantikan para selebritis sudah mengaburkan mana halal dan mana haram. Contoh kasus, penggunaan produk kosmetik peremajaan kulit yang mengandung ekstrak plasenta yang jelas diambil dari plasenta manusia masih banyak ditemui di tempat salon-salon wajah.

Kurang knitisnya konsumen muslim terhadap produk halal. Konsumen Indonesia searang ini sanagt kritis dlam memakai produk, tentu mereka ingin merasa puas terhadapa apa yang mereka beli. Umumnya mereka kritis terhadap kulaitas produk yang meek beli, namun kritis terhdap produk halal di negeri kita sangat mempeihatinkan. Jarang muslimah membeli kosmetik mengeluarkan kata kritis "halal tidak?"

\section{Tips Memilih Kosmetika Halal}

Dengan adanya usaha sertifikasi halal yang dilakukan oleh MUI maka konsumen muslim lebih mudah dalam memilih produk kosmetika yang telah dijamin kehalalannya oleh MUI. Cara memilinnya adalah sbb:

Jika produk kosmetika tersebut dalam kemasannya telah mencantumkan nomor KD (nomor pendaftaran pada Badan POM yang menunjukkan produk diproduksi didalam negeri) maka lihat apakah ada label halalnya, jika ada maka kehalalannya sudah terjamin karena untuk dapat diizinkan mencantumkan label halal dalam kemasannya maka harus mendapatkan sertifikat halal dari MUI. Jika tidak ada label halalnya maka berarti kehalalannya belum ada yang menjamin.

Untuk produk impor, lihat apakah sudah memiliki nomor KL pada kemasannya, jika sudah perhatikan bahasa yang digunakan dalam kemasan, jika berbahasa Indonesia maka perhatikan label halalnya, jika ada maka kehalalannya sudah tejamin seperti nomor 1 diatas. Untuk produk impor dari negara mayoritas muslim seperti Malaysia, perhatikan label halalnya, jika ada berarti kehalalannya sudah ada yang menjamin. Untuk produk impor lainnya, jika tidak ada label halalnya harus dihindari dan kita pun harus berhati-hati apabila produk tersebut berlabel halal tetapi diproduksi oleh negara mayoritas non muslim, untuk kasus ini perlu menanyakan keabsahan label halalnya ke LPPOM MUI.

Daftar produk halal dapat dilihat di Jurnal Halal terbitan LPPOM MUI atau di http://www.www.halalmui.org, daftar ini memuat produk yang telah mendapatkan sertifikat halal dari MUI.

\section{Daftar pustaka}

1. Muchtaridi. 2004. Ekstrak plasenta antar khasiat dan kehalalan. Majalah NOOR. Edisi 05/Mei/2004

2. Watanabe et al. 2002. J. Nutr. Sci., Vitaminol. 48(1); 36-39

3. Insan, Abdul Halim. 2010. The Halal Index: Pig Based Pharmaceuticals. Vol 1. National Library of Malaysia 